\title{
TERMINY I RELACJE W DWUJĘZYCZNYCH TEKSTACH KONSTYTUCJI MiĘDZYNARODOWA KONFERENCJA NAUKOWA LUBLIN, 4-5 WRZEŚNIA 2015 R.
}

W dniach 4-5 września 2015 r. w Katolickim Uniwersytecie Lubelskim Jana Pawła II w Lublinie odbyła się Międzynarodowa Konferencja Naukowa pt. „Terminy i relacje w dwujęzycznych tekstach konstytucji”. Organizatorami tego wydarzenia byli: L'UFR de Langue Française à l'Université Paris-Sorbonne, Instytut Filologii Romańskiej Uniwersytetu Jagiellońskiego oraz Katedra Kościelnego Prawa Publicznego i Konstytucyjnego KUL.

Otwarcia konferencji dokonał ks. dr hab. Mirosław Sitarz, prof. KUL - kierownik Katedry Kościelnego Prawa Publicznego i Konstytucyjnego KUL, który powitał wszystkich gości i podziękował członkom Rady Naukowej i członkom Komitetu Organizacyjnego za podjęcie przygotowania merytorycznego i organizacyjnego konferencji. W sposób szczególny podziękował prof. Dorocie Śliwie, która była inicjatorem i pomysłodawcą tego przedsięwzięcia naukowego.

W imieniu Rektora KUL i całego Kolegium Rektorskiego głos zabrała dr hab. Urszula Paprocka-Piotrowska, prof. KUL która podkreśliła, że organizowanie tego rodzaju spotkań naukowych jest niezwykle ważne. Prorektor wyraziła radość, iż partnerami są Uniwersytet Jagielloński i Uniwersytet w Sorbonie.

W ramach otwarcia głos zabrał również prof. Olivier Soutet - dyrektor Instytutu w Sorbonie. Z kolei w imieniu dyrekcji Instytutu Filologii Romańskiej UJ słowa powitania skierowała pani Maryla Gawron-Zaborska, wyrażając radość, że w Katolickim Uniwersytecie Lubelskim Jana Pawła II spotykają się naukowcy z ośrodków krajowych i zagranicznych.

Program konferencji obejmował sześć sesji, w których zostały przedłożone po dwa wykłady. Cztery odbyły się w pierwszym dniu obrad i dwie w następnym. Referaty zaprezentowało łącznie 12 prelegentów reprezentujących trzy państwa (Chorwacja, Francja i Polska), z sześciu ośrodków naukowych (Universite Paris 4 - Sorbonne, Université de Bourgogne - 
Université de Zagreb, Uniwersytet Warszawski, Instytut Studiów Franciszkańskich w Krakowie, Uniwersytet Jagielloński i Katolicki Uniwersytet Lubelski Jana Pawła II).

Sesji pierwszej przewodniczył prof. M. Sitarz. W jej ramach referat nt. „Analogiczna teoria znaczenia terminów językowych. Elementy metafizyki języ$k a$ " wygłosił ks. prof. dr hab. Andrzej Maryniarczyk, SDB (KUL). Prelegent w swoim wystąpieniu przedstawił różne koncepcje znaczenia oraz analogiczną koncepcję znaczenia. Prof. A. Maryniarczyk wskazał, że w semantyce obowiązują cztery podstawowe teorie znaczenia: 1) asocjanistyczna (znaczenie danego słowa/zdania umieszcza się w sferze psychicznej), 2) konotacyjna (znaczenie umieszcza się w przedmiocie materialnym), 3) ideologiczna (znaczenie umieszcza się w tzw. trzecim świecie, w idealnym świecie) i 4) abstrakcjonistyczna (znaczenie zredukowane do pojęcia). Przechodząc do analizy analogicznej koncepcji znaczenia, Prelegent wyjaśnił, że analogia to poznanie zwielokrotnione. Podstawą wielości jest dostrzeżone podobieństwo, jak również zachowana różnorodność. Analogia metafory polega na oderwaniu jakiejś cechy z jednego przedmiotu i przeniesienie jej na drugi. Ksiądz Profesor wyróżnił analogię atrybucji (np. „zdrowe powietrze”) i analogię proporcji (np. „istota żywa”).

Następnie prof. dr hab. Krzysztof Bogacki (UW) zaprezentował referat pt. „Primitifs sémantiques, prédicats et ontologies (à partir des textes constitutionnels - une réflexion terminologique sur les ontologies et primitifs sémantiques en philosophie, en linguistique et en informatique)" [Prymitywy semantyczne, predykaty i ontologie (na podstawie tekstów konstytucyjnych - refleksja terminologiczna na temat ontologii i prymitywów semantycznych w filozofii, lingwistyce $i$ informatyce)] Wskazał na trzy zasadnicze pojęcia, które scharakteryzował, tj. 1) pojęcie ontologii, 2) pojęcie predykatów i 3) pojęcie prymitywów semantycznych. Prelegent zauważył, że jeszcze nie tak dawno ontologią zajmowali się niemal wyłącznie filozofowie i logicy, którzy dodatkowo interesowali się tzw. prymitywami semantycznymi używając pojęcia predykatów semantycznych. Współcześnie odwoływanie się do ontologii jest nieodzowne także wówczas, gdy wykorzystywany jest komputer do automatycznego wyszukiwania treści zawartych w tekstach. Również informatykom nieobce jest pojęcie predykatów. W referacie Prelegent porównał podejście językoznawców i informatyków do ontologii i wskazywał na punkty zbieżne i różnice w użyciu terminów "ontologia" i „predykat”.

Sesja zakończyła się dyskusją w której udział wzięli prof. D. Śliwa, prof. A. Maryniarczyk oraz prof. O. Soutet

Sesji drugiej przewodniczył prof. Samir Bajrić. Referat nt. „Comment parler de constitution à Rome?" [Jak mówić o konstytucji w Rzymie] wygło- 
siła Michèle Ducos (Universite Paris 4 - Sorbonne). W swoim referacie zwróciła uwagę, że w starożytnym Rzymie nie było konstytucji w sensie formalnym i materialnym. Społeczeństwo nie powstało poprzez ustawy, ale przez zwyczaje i normy społeczne. Prelegentka wskazała na różne rodzaje aktów normatywnych, które powstały w starożytnym Rzymie, zarówno o charakterze ogólnym (edykt), jak i szczególnym (dekret, reskrypt, odpowiedź pisemna, wyrok, odpowiedź administracyjna).

Prof. Olivier Soutet (Universite Paris 4 - Sorbonne), zaprezentował wykład pt. "Analyse lexicologique et historique de constitution, loi, règle et charte" [Analiza leksykalna i historyczna pojęć: konstytucja, ustawa, zasada $i$ karta]. Prelegent w swoim wystąpieniu podał przesłanki etymologiczne i chronologiczne dotyczące znaczenia prawnego i konstytucyjnego pojęć: konstytucja, ustawa, zasada i karta. Wskazał także na charakter religijnych tych pojęć. Prelegent zauważył, że w przypadku dokumentów papieskich stosuje się termin w liczbie pojedynczej „,konstytucja apostolska” a w przypadku prawa zakonnego już w liczbie mnogiej - "konstytucje zakonne". Następnie Profesor wskazał na problem konotacji pojęcia konstytucja i jego stosowanie. Pierwsza konstytucja we Francji powstała w 1791 r. w okresie Wielkiej Rewolucji i wprowadziła ustrój I Republiki. Kolejny dokument „Karta konstytucyjna” z 1815 r. została wprowadzona po obaleniu Cesarstwa Napoleona Bonaparte. Powstała wtedy II Republika, przemieniona później przez Napoleona III, który doprowadził do powstania II Cesarstwa. Kiedy w 1870 r., cesarz został obalony, powstał problem jaki wprowadzić ustrój. Przez 5 lat, Francja nie miała w sensie ścisłym ustroju. Nie chciano wprowadzić ustroju republikańskiego w jego ówczesnym rozumieniu, ponieważ, jak to określił Profesor „źle się kojarzył”. Odwołano się więc do starożytnego rozumienia republiki - res publica i dlatego dopiero w 1875 r. uchwalono ustawy konstytucyjne tzw. "trzecią kartę”. Kolejna konstytucja została uchwalona dopiero w okresie reżymu Vichy w czasie II wojny światowej.

Na zakończenie odbyła się dyskusja, w której głos zabrał o. A. Zając, prof. M. Sitarz, prof. D. Śliwa i prof. O. Soutet.

Sesji trzeciej przewodniczył o. Andrzej Zając. Jako pierwszy referat pt. „Funzione dell'attività definitoria nel diritto canonico. Riferimenti alla traslazione latino-polacca dei testi costituzionali di alcuni Istituti religiosi" [Funkcja tworzenia definicji w prawie kanonicznym. Odniesienia do ttumaczenia łacinskich-polski w konstytucjach niektórych instytutów zakonnych] wygłosił o. dr Przemysław Michowicz, OFMConv (Instytut Studiów Franciszkańskich w Krakowie). W swoim referacie Prelegent wskazał, że brak ogólnej teorii prawa Kościoła, sprawia, że trudno jest przedstawić problem tworzenia 
definicji instytucji i pojęć prawnych stosowanych w prawie kanonicznym, a szczególnie w konstytucjach niektórych instytutów zakonnych. Po promulgacji Kodeksu Prawa Kanonicznego z 1983 r. można zauważyć pewną ostrożność w definiowaniu instytucji prawnych i co występowało także $\mathrm{w}$ podstawowych konstytucjach instytutów zakonnych. Zadanie definiowania języka prawno-kanonicznego to raczej doktryna określenia ich przez opinie osób autorytatywnych, które posiadają różną wartość hierarchiczna, pod warunkiem, że podstawą ich opinii jest dokładna analiza tekstów prawnych. Niezależnie od tych ewidentnych trudności, nie można całkowicie wykluczyć możliwości tworzenia niektórych rodzajów definicji prawnych. Prelegent wskazał na konieczność porównania tych samych tekstów konstytucyjnych wybranych instytutów zakonnych dla wskazania pewnej dynamiki oraz możliwych dostosowań językowych, jakie istnieją między tłumaczeniami dokumentu z języka łacińskiego na polski.

Dr Anna Słowikowska (KUL) przedłożyła referat nt. „Interpretacja pojęcia munus w konstytucji dogmatycznej o Kościele «Lumen gentium» (1964)". Celem wystąpienia była interpretacja pojęcia munus w takim kształcie, jaki został mu nadany w konstytucji Lumen gentium i dołączonej do niej wstępnej nocie wyjaśniającej (Nota explicativa praevia). Pani Doktor w pierwszej kolejności przedstawiła językowe znaczenie pojęcia munus. Zgodnie z porządkiem semantycznym do podstawowych znaczeń tego wyrazu należą: zadanie, obowiązek, urząd, praca, funkcja. Następnie A. Słowikowska przeanalizowała występowanie pojęcia munus w konstytucji Lumen gentium. Wskazała, że termin ten występuje 49 razy w samej konstytucji i 6 razy w Nota explicativa praevia. Najczęściej Ojcowie soborowi używali tego terminu w znaczeniu: urząd, misja, zadanie, funkcja. Prelegentka zwróciła również uwagę na liczne rozbieżności i błędy w przekładach z języka łacińskiego, który jest oficjalnym językiem Kościoła. Dlatego też, jeżeli tekst oryginalny jest opublikowany w języku łacińskim, to w takim obowiązuje. Trzecim punktem wystąpienia było wskazanie implikacji wieloznaczności pojęcia munus dla rozumienia konstytucji Lumen gentium.

W dyskusji głos zabrali prof. D. Śliwa, Pani prof. M. Ducos oraz o. dr P. Michowicz.

Ostatniej sesji pierwszego dnia sympozjum przewodniczyła M. Ducos. Prelekcję nt. "Peuples constitutifs et identités linguistiques en Bosnie-Herzégovine" [Narody konstytucyjne i tożsamości lingwistyczne w Bośni i Hercegowinie] wygłosił prof. Samir Bajrić (Université de Bourgogne - Université de Zagreb). Prelegent wskazał na problem stworzenia związku między nazwą „serbsko-chorwacki” i nazwą Jugosławia, ale nie w takim samym zna- 
czeniu etnonimu ,jugosłowiański” jaki ma etnonim „francuski” - Francja rozpatrywana jako państwo, naród - odnosi się do narodu francuskiego. Rygorystyczne rozróżnienie, które narody zamieszkujące Półwysep Bałkański stanowia, jako dziedzictwo austro-węgierskie, między nacionalnost („narodowość”, „przynależności do narodu," niem.: Volksangehörigkeit) i državljanstvo („obywatelstwo”, „przynależność do Państwa” niem.: Staatsangehörigkeit) zderza się z francuskim, zachodnim rozumieniem, gdzie naród i państwo są zwartym kryterium-odniesieniem. Polityka językowa, tak samo jak i polityka wspólnot społecznych i religijnych, które dzisiaj tworzą Bośnię i Hercegowinę, dziwny relikt, „mozaikę narodów i tradycji", które kiedyś stanowiły drugą Jugosławię (1941-1991), komplikuje złożoność relacji, zarówno instytucjonalnych, jak i ludzkich między jej narodami składowymi. Nazwy ustalone w porozumieniach z Dayton (1995 r.) i odnoszące się do podmiotów politycznych, jak również zainteresowanych narodów i mniejszości, takich jak Federacja bośniacko-chorwacka/muzułmańsko-chorwacka, Republika Serbska (serbska jednostka polityczna w Bośni i Hercegowinie), Chorwaci/Bośnio-Chorwaci, Serbowie/Bośnio-Serbowie, Bośniacy, Bośniacy/muzułmanie/bośniaccy-muzułmanie, itp, tworzą bardzo szeroki obszar, w którym przenikają się i nakładają wymagania językowe i realia wieloetniczne oraz wielowyznaniowe.

„Mariage, PACS et concubinage et leurs équivalents terminologiques et juridiques en Croate" [Małżeństwo, konkubinat i PACS oraz ich ekwiwalenty terminologiczne i prawne w Chorwacji] stanowił przedmiot wystąpienia prof. Dubravki Saulan (Universite Paris 4 - Sorbonne). W swoim wystąpieniu Prelegentka stwierdziła, że to związek dwóch osób (bez względu na płeć) jest aktem prawnym i sformalizowanym jako nowa rodzina w Unii Europejskiej. Prelegentka przedstawiła pojęcia „,małżeństwo", „PACS” i „,konkubinat” w języku francuskim oraz „brak" „životno partnerstvo" w języku chorwackim. Pani Profesor ponadto przegląd terminologiczny stopnia rozpadu przymierza rodzinnego w obu tradycjach prawnych (rozwód, separacja). Dzięki nim, zdaniem prof. D. Soulan łatwiej jest zrozumieć różnice w konceptualizacji warunków określenia danego rodzaju związku. Prelegentka stwierdziła, że małżeństwo od związku formalnego (PACS) różni się tylko tym, że małżeństwo jest związkiem kobiety i mężczyzny, natomiast PACS może być także związkiem dwóch osób tej samej płci.

Na zakończenie wywiązała się żywa dyskusja odnośnie do stwierdzenia Prelegentki na temat różnicy między małżeństwem i PACS, związków sakramentalnych i niesakramentalnych oraz znaczenia instytucji separacji w prawie państwowym, jak i kościelnym. Głos zabrali prof. D. Śliwa, ks. prof. M. Sitarz oraz M. Gawron-Zaborska. 
Drugi dzień obrad rozpoczął się Mszą św. w Kościele Akademickim w intencji zmarłej 1 lipca 2015 r. prof. dr hab. Haliny Grzmil-Tylutki (Uniwersytet Jagielloński), która od początku zaangażowana była w prace merytoryczne i organizacyjne konferencji.

Sesji piątej przewodniczył prof. Krzysztof Bogacki. Pierwszy referat pt. „La Diète, la diétine, le Maréchal de la Diète, ... - de la Constitution du 3 mai 1791 à la Constitution du 2 avril 1997 ou que doit faire le traducteur pour que la Pologne ne soit plus située "nulle part »?" [Sejm, sejmik, Marszałek Sejmu, ... - od Konstytucji 3 maja 1791 r. do Konstytucji z 2 kwietnia 1997 r. lub co musi zrobić tłumacz aby Polska już nie znajdowała się "nigdzie"?] wygłosiła mgr Maryla Gawron-Zaborska (Uniwersytet Jagielloński). W swoim wystąpieniu Prelegentka przedstawiła sytuacje, w których znalazła się jako tłumacz pracujący w Ambasadzie Francuskiej w Krakowie, podczas spotkań urzędników francuskich z przedstawicielami polskich organów samorządowych. Podała przykład, gdy tłumaczenie wyrazu „sejmik" na "la diéti$n e$ " wywoływało uśmiech wśród francuskich urzędników i porównała to do sytuacji, gdyby w Polsce ktoś mówił o „bundestagiku”, "kneseciku”. Prelegentka przedstawiła zastosowane słownictwo w tekstach konstytucji: tłumaczenie na język francuski Konstytucji 3 maja 1791 r., Konstytucja Księstwa Warszawskiego z 1807 r. w oryginale sporządzona po francusku, Karta Konstytucyjna dla Królestwa Kongresowego z 1815 r. nadana przez Cara Aleksandra I także w oryginale po francusku, Konstytucja Wolnego Miasta Kraków 1815 r. także we francuskim oryginale oraz Konstytucja marcowa z 1921 r. w tłumaczeniu na język francuski. W konkluzji swojego wystąpienia Prelegentka udzieliła praktycznej rady dla tłumaczy, aby $\mathrm{w}$ trakcie swojej pracy stosowali nazewnictwa historycznego wobec tych, którzy mieli do czynienia z terminologią francuską i polską a w przypadku pozostałych osób - nazewnictwa zbliżonego.

Wykład nt. „Zarys klasyfikacji semantycznej i modalnej czasowników polskich i francuskich wystęujacych z syntagmami łacińskimi w tekstach prawa" przedłożyła mgr Ilona Krasoń (KUL). W swoim wystąpieniu przedstawiła problem stosowania łacińskich paremii w tekstach prawnych i prawniczych we Francji i Polsce. Prelegentka przedstawiła podstawową typologię tekstów prawnych: teksty prawne (kodeksy, ustawy, rozporządzenia, dekrety, itp.) oraz teksty prawnicze (podręczniki, artykuły, komentarze i prace doktorskie). Następnie przedstawiła klasyfikację semantyczną prédicats verbaux (orzeczenia) w języku polskim i francuskim. Prelegentka podała przykłady takich czasowników zarówno w języku polskim i francuskim oraz zwrotów łacińskich. Każdy tekst prawny ma charakter normatywny, a zatem powinien mieć tryb deontyczny. 
Na zakończenie sesji odbyła się dyskusja na temat tzw. „wtrąceń łacińskich", w której uczestniczyli: S. Bajrić, M. Ducos, O. Soutet oraz ks.M. Sitarz.

Ostatnią sesję poprowadził prof. Olivier Soutet. Referat nt. „Les verbes garantir et assurer et leurs équivalents polonais dans le texte constitutionnel contemporain d'un Etat et dans "Gaudium et spes " (1965)" [Czasowniki garantir i assurer oraz ich ekwiwalenty polskie w tekstach wspótczesnych konstytucji państwowych oraz Gaudium et spes (1965)] wygłosiła prof. Dorota Śliwa - pomysłodawca przedmiotowego wydarzenia naukowego. W swoim wystąpieniu Pani Profesor bazowała na tekstach konstytucji Francji i Polski oraz ich tłumaczeń na język polski i francuski. Prelegentka wskazała etymologię czasowników garantir, assurer, gwarantować i zabezpieczać oraz na konstrukcje semantyczne występujące $\mathrm{w}$ badanych tekstach $\mathrm{w}$ danych językach.

Następnie odbyła się dyskusja, w której głos zabrała Pani M. Gawron-Zaborska, prof. S. Bajrić, o. A. Zając.

Na końcu, w imieniu Organizatorów głos zabrał prof. O. Soutet, który podsumował poszczególne wystąpienia oraz prof. D. Śliwa, która dziękując za owocne obrady, podziękowała za aktywną obecność, poinformowała o planowanej publikacji artykułów z konferencji oraz dokonała zamknięcia konferencji.

Agnieszka Romanko* Urszula Wasilewicz

\footnotetext{
* Dr, Katolicki Uniwersytet Lubelski Jana Pawła II

** Dr, absolwentka Katolickiego Uniwersytetu Lubelskiego Jana Pawła II
} 